Kredo 4 (2021)
KREDO: Jurnal Ilmiah Bahasa dan Sastra
Terakreditasi Sinta 4 berdasarkan Keputusan Direktorat
Jenderal Penguatan Riset dan Pengembangan,
Kementerian Riset, Teknologi dan Pendidikan Tinggi
Republik Indonesia
Nomor: 23/E/KPT/2019. 08 Agustus 2019
https://jurnal.umk.ac.id/index.php/kredo/index

\title{
PENGEMBANGAN ALAT PENILAIAN PEMBELAJARAN BAHASA INDONESIA BERBASIS KOMPETENSI MENGGUNAKAN PENDEKATAN KONTEKSTUAL DI SMA PAPUA KOTA SORONG
}

\author{
Irwan soulisa ${ }^{1}$, Peter Manuputty ${ }^{2}$ \\ soulisairwan@gmail.com ${ }_{\llcorner}^{1}$ petermanuputty3@gmail.com ${ }^{2}$ \\ Universitas Victory Sorong, Indonesia
}

Info Artikel :
Sejarah Artikel
Diterima
12 Juli 2020
Disetujui
18 April 2021
Dipublikasikan
21 April 2021
Keywords :
Assessment Tool Baser
Competence Contextua
Model High School Papua.

\section{Kata Kunci}

Alat penilaian, berbasis kompetensi, model kontekstual, SMA Papua.

\begin{abstract}
Learning assessment is very important to find out the ability and expertise of students in the learning process. The strengths and weaknesses of students during the learning process can certainly be identified with in-depth analysis through assessments carried out by the teacher. This research uses descriptive qualitative and quantitative methods using a contextual model. The technique of collecting data through observation, unstructured interviews aims to determine the use of the development of competency-based learning tools for SMA Papua in Sorong City in 2020. The data analysis technique is descriptive qualitative which includes process analysis and product data analysis for midterm and semester exams prepared by educators and the validity used in this study is democratic validity. The data analysis method : is through: 1) classical assumption test (data reliability and validity test) to see the effect (linkage) between the independent and dependent variables. In addition, literature / literature review is to parse studies / frame of reference / theoretical regarding the independent and dependent variables. The results of the study stated that the development of competency-based learning tools in SMA Papua in the city of Sorong with the model of developing test specifications, writing the items, analyzing the items, analyzing the items and answers, implementing the test, assembling the questions.
\end{abstract}




Kredo 4 (2021)
KREDO: Jurnal Ilmiah Bahasa dan Sastra
Terakreditasi Sinta 4 berdasarkan Keputusan Direktorat
Jenderal Penguatan Riset dan Pengembangan,
Kementerian Riset, Teknologi dan Pendidikan Tinggi
Republik Indonesia
Nomor: 23/E/KPT/2019. 08 Agustus 2019
https://jurnal.umk.ac.id/index.php/kredo/index

\section{PENDAHULUAN}

Penilaian dalam proses pembelajaran memiliki peran yang sangat penting untuk mengetahui tingkat keberhasilan pembelajaran. Keunggulan dan kekurangan selama proses pembelajaran yang didalamnya melibatkan siswa dalam belajar dapat teratasi dengan baik jika penilaian yang digunakan benar-benar mengetahui karakteristik siswa secara mendalam. Keberhasilan penilaian pembelajaran salahsatunya ditentukan dalam analisis individu siswa secara akurat sehingga menghasilkan temuan pembelajaran yang mampu meningkatkan keahlian siswa di bidang yang masih sulit dipahaminya.

Setiap kurikulum punya orientasi filosofis dan teoretik tertentu sehingga berimplikasi pada proses pembelajaran beserta penilaian dan hasil belajar. Penilaian dalam dunia pendidikan berarti memertimbangkan hasil belajar peserta didik, cara pembelajaran guru, kegiatan belajar, kurikulum atau program pendidikan, dan sebagainya. Berdasarkan standar nasional pendidikan yang tertuang pada peraturan pemerintah RI No 19 tahun 2005 tersebut menyatakan bahwa penilaian adalah proses pengumpulan serta pengolahan informasi yang digunakan mengukur pencapaian hasil belajar siswa.

Permasalahan yang terjadi di lapangan selama proses pembelajaran salahsatunya terjadi karena pemangku pendidikan masih kurang melakukan inovasi atau pembaharuan di tiap unsur pendidikan meliputi perangkat pembelajaran, media, model, inovasi ketertarikan atau keaktifan siswa dalam ruang lingkup pendidikan. Kualitas pendidikan menjadi arah yang dituju untuk memberikan perubahan yang nyata sesuai dengan problematika yang terjadi dalam pembelajaran.

Di pihak lain Brown (2004:3) menyatakan bahwa penilaian memiliki makna yang sama dengan tes yang sama-sama mengacu pada fungsinya sebagai alat untuk melakukan pengukuran, pengetahuan, kemampuan, dan kinerja yang dilakukan oleh seseorang pada ranah atau tujuan yang digunakan dalam proses kegiatan. Penilaian itu sendiri memiliki tiga poin penting yang harus ada dalam tiap kegiatan meliputi tes yang digunakan untuk mengukur teknik melalui butirbutir yang menuntut adanya jawaban atas kinerja. Kedua, tes digunakan sebagai alat untuk mengukur kemampuan diri seseorang melalui pengetahuan umum maupun pengetahuan khusus. Ketiga, tes digunakan untuk mengukur pengetahuan, kemampuan, maupun kinerja pada diri seseorang, seperti pengetahuan, keterampilan, kemampuan, kinerja dan hal-hal yang dapat digunakan untuk mengetahui sasaran penggunaan penilaian. 


Kredo 4 (2021)
KREDO: Jurnal Ilmiah Bahasa dan Sastra
Terakreditasi Sinta 4 berdasarkan Keputusan Direktorat
Jenderal Penguatan Riset dan Pengembangan,
Kementerian Riset, Teknologi dan Pendidikan Tinggi
Republik Indonesia
Nomor: 23/E/KPT/2019. 08 Agustus 2019
https://jurnal.umk.ac.id/index.php/kredo/index

Penilaian hasil belajar salahsatunya diketahui melalui aspek afektif, psikomotorik, dan kognitif. Penerapan penilaian hasil belajar pada penelitian ini dilakukan di SMA Papua Kota Sorong berdaskan model penilaian berbasis kompetensi. Penelitian ini idasarkan atas kebutuhan dan permasalahan yang muncul bahwa kualitas pembelajaran masih perlu ditingkatkan dan diketahui akar masalah melalui aktivitas, media, model, dan perangkat pembelajaran yang melatarbelakangi adanya masalah dalam sistem penilaian.

Pada mata pelajaran bahasa Indonesia di tingkat SMA proses pembelajaran mengarah pada pemahaman mahasiswa terkait dengan keterampilan berbahasa Indonesia baik itu keterampilan secara produktif maupun keterampilan secara reseptif. Praktik pembelajaran di SMA memerlukan persiapan mulai dari perangkat pembelajaran, model, media, teknik pembelajaran, penilaian, dan contoh yang memudahkan pemahaman siswa.

Selain itu, Praktik pembelajaran sehari-hari di sekolah masih mengalami berbagai persoalan dengan perangkat pembelajaran yang digunakan untuk mengoperasikan jalannya pembelajaran. Diantara masalah ini peneliti memperhatikan hal-hal yang tidak diperhatikan oleh tenaga pendidik antara lain: (1) banyak indikator dan tujuan pembelajaran yang dirumuskan oleh guru masih cenderung pada kemampuan kognisi, afeksi, dan psikomotor tingkat rendah. (2) masih banyak guru menggunakan bahan ajar yang cendrung kognivistik. (3) pemampaatan sumber dan media pembelajaran yang tersedia dilingkungan sekitar siswa belum optimal dan kurang menggunkan situasi kehidupan rill. (4) penilaian proses juga kurang berjalan optimal karena keterbatasan kemampuan pengembangan perangkat instrument asesmen, (Sadun, 2013:2).

Selanjutnya, Kegiatan penilaian yang dilakukan peneliti dengan mengandalkan teknik pengamatan tampaknya kurang dapat dipertanggungjawabkan karena unsure subjektivitas penilai sangat berperan. Berdasarkan informasi yang diperoleh dari penelitian penilaian terhadap hasil belajar peserta didik dipergunakan sebagai salah satu sarana untuk menilai kualitas pembelajaran pendidik yang dilakukan di SMA Papua Kota Sorong.

Berdasarkan hasil pengamatan peneliti, penelitian penilaian sebelumnya sangat kurang sekali untuk mengetahui kompetensi apa yang sudah, belum, atau kurang dikuasai pendidik dan karenanya dapat dilakukan tindakan dalam penelitian ini antara lain pemahaman pada karakteristik ujian atau tes, pembuatan naskah butir soal, penelaahan butir soal, pelaksanaan uji

\section{1 | Jurnal Kredo}

Vol. 4 No. 22021 


Kredo 4 (2021)
KREDO: Jurnal Ilmiah Bahasa dan Sastra
Terakreditasi Sinta 4 berdasarkan Keputusan Direktorat
Jenderal Penguatan Riset dan Pengembangan,
Kementerian Riset, Teknologi dan Pendidikan Tinggi
Republik Indonesia
Nomor: 23/E/KPT/2019. 08 Agustus 2019
https://jurnal.umk.ac.id/index.php/kredo/index

coba, analisis butir soal dan dilakukan analisis jawaban butir soal ujian setelah dilaksanakan ujian melalui indikator dalam penelitian khususnya di SMA Papua di kota Sorong.

Penelitian yang dilakukan oleh Fawzi (2016), Bastaman Sasmito Aji, M. E Winarno (2016), Suryanti, Sukestyarno, Fakhrudin (2013) menyatakan bahwa penilaian memiliki kedudukan yang sangat penting dalam proses pembelajaran untuk mengetahui karakteristik tiap individu mengenai kemampuan dan keahlian yang dimilikinya. Pengembangan penilaian dilakukan untuk mengetahui dan melengkapi kebutuhan di lapangan sebagai langkah menentukan lebih mendalam terkait permasalahan yang dihadapi selama praktik atau kegiatan penelitian.

Selain itu, peneliti melakukan tafsiran terhadap kondisi yang ada sekarang dan merupakan prediksi penampilan pada masa mendatang. Proses penilaian yang baru sampai pada tingkat pembuatan pertimbangan sebenarnya harus diikuti oleh adanya pengambilan tindakan yaitu kepala sekolah akan mempertimbangkan bahkan bahwa pendekatan dan metode yang disarankan oleh kurikulum akan lebih efektif daripada pendekatan yang dianut sebelumnya.

Namun dari sisi kedisiplinan perangkat mengajar, pemerintah minim sekali memperhatikan hal tersebut. Oleh karena itu, perhatian khusus dinas pendidikan untuk mengembangkan maupun peningkatan perangkat mengajar pendidik harus diperhatikan demi kemajuan pendidikan di kota sorong. Sedangkan disisi lain, permintaan terhadap tenaga pendidik terutama kesiapan mengajar, perangkat alat pembelajaran sangat tinggi karena jumlah pendidik, kebutuhan pengembangan alat pembelajaran maupun perangkat lain bagi peserta didik di sekolah semakin meningkat dan cepat, dan tuntutan kurikulum semakin meningkat sesuai perkembangan zaman. Dengan demikian, usaha seorang pendidik disesuaikan dengan perkembangan zaman.

Berdasarkan dengan permasalahan di atas, maka peneliti melakukan penelitian di SMA Papua di kota sorong sebagai objek dan permasalah-permasalahan tersebut tidak dicari solusi pemecahannya secara serius maka akan berpengaruh negatif secara langsung pada penilaian alat pembelajaran guru (termasuk pelayanan publik), khususnya di SMA Papua maupuan dalam lingkup pendidikan di kota sorong. Sehubungan dengan itu, akhirnya peneliti merumuskan judul penelitiannya, sebagai berikut: upaya pengembangan alat pembelajaran berbasis kompetensi menggunakan pendekatan kontekstual pada SMA Papua di kota sorong. 


Kredo 4 (2021)
KREDO: Jurnal Ilmiah Bahasa dan Sastra
Terakreditasi Sinta 4 berdasarkan Keputusan Direktorat
Jenderal Penguatan Riset dan Pengembangan,
Kementerian Riset, Teknologi dan Pendidikan Tinggi
Republik Indonesia
Nomor: 23/E/KPT/2019. 08 Agustus 2019
https://jurnal.umk.ac.id/index.php/kredo/index

\section{KAJIAN TEORI}

\section{A. Hakikat Penilaian}

Suarga (2019) menyatakan bahwa penilaian sebagai suatu proses yang dilakukan melalui langkahlangkah perencanaan, penyusunan alat penilaian dan proses pengumpulan informasi melalui bukti yang menunjukkan pencapaian hasul belajar siswa, pengolahan dan penggunaan informasi tentang hasil belajar siswa. Subagia dann Wiratma (2016) menyatakan bahwa pemahaman tentang penilaian secara istilah dalam bahasa Indonesia memiliki kesamaan dengan evaluasi (evaluation) dan sekarang ini terkenal dengan istilah asesmen (assessment). Arifin (dalam Aji dan Winarno, 2016) menjelaskan penilaian adalah suatu proses atau kegiatan yang sistematis dan berkesinambungan untuk mengumpulkan informasi tentang proses dan hasil belajar siswa dalam rangka menentukan keputusankeputusan berdasarkan kriteria dan perimbangan tertentu. Juliantine (dalam Wulandari, Situmorang, Dewi, 2019) memaparkan bahwa penilaian merupakan cara mengumpulkan informasi yang valid dan reliabel untuk mengetahui keberhasilan proses pembelajaran.

\section{B. Tujuan Penilaian}

Poerwanti (dalam Aji dan Winarno, 2016) memaparkan bahwa 583 | Jurnal Kredo

Vol. 4 No. 22021 tujuan penilaian untuk mengetahui seberapa jauh keberhasilan guru dalam melaksanakan proses pembelajaran dan digunakan untuk umpan balik bagi guru dalam merencakan proses pembelajaran selanjutnya. Asesmen atau penilaian menurut Arikunto (dalam Wahyudi, 2010) memiliki beberapa tujuan dan fungsi meliputi, (1) penilaian berfungsi selektif, (2) penilaian berfungsi diagnostic, (3) penilaian berfungsi sebagai penempatan, dan penilaian berfungsi sebagai pengukur keberhasilan. Sudjana (dalam Wahyudi, 2010) memaparkan bahwa fungsi dan tujuan penilaian meliputi, mendeksripsikan kecakapan belajar para siswa, (2) mengetahui keberhasilan proses pendidikan dan pengajaran, (3) menentukan tindak lanjut hasil penilaian, (4) memberikan pertanggungjawaban dari pihak sekolah kepada stakeholders, (5) sebagai dasar umpan balik bagi perbaikan proses pembelajaran.

\section{Hakikat Pembelajaran Berbasis Kompetensi}

Fich dan Crunkilton (dalam Pardjono dan Windiyati, 2012) menjelaskan bahwa kompetensi sebagai penguasaan terhadap suatu tugas, keterampilan, sikap, dan apresiasi diperlukan untuk menunjang keberhasilan. Suteja (2017) menyatakan bahwa kurikulum berbasis kompetensi merupakan suatu konsep kurikulum 
Kredo 4 (2021)

KREDO: Jurnal Ilmiah Bahasa dan Sastra

Terakreditasi Sinta 4 berdasarkan Keputusan Direktorat

Jenderal Penguatan Riset dan Pengembangan,

Kementerian Riset, Teknologi dan Pendidikan Tinggi

Republik Indonesia

Nomor: 23/E/KPT/2019. 08 Agustus 2019

https://jurnal.umk.ac.id/index.php/kredo/index

yang menekankan pada aspek pengembangan kemampuan kompetensi tugas-tugas dengan standar tertentu sehingga hasilnya dapat dirasakan oleh siswa berupa penguasaan terhadap seperangkat kompetensi antara lain seperangkat pengetahuan, kemampuan, sikap, dan minat siswa dalam melakukan sesuatu dalam bentuk

kemahiran dalam belajar dengan penuh tanggung jawab.

\section{Pendekatan Kontekstual}

Hosnan (dalam Zulaiha, 2016) menjelaskan mengenai definisi secara bahasa dari kata contextual yang berasal dari kata rontex yang berarti hubungan, konteks, suasana, atau keadaan. Arti contextual yakni berhubungan dengan suasana (konteks).

Zahorik (dalam Sulianto, 2008) memaparkan terdapat lima elemen dalam praktik pembelajaran kontekstual yakni: 1) pengaktifan pengetahuan yang sudah ada; 2) pemerolehan pengetahuan baru dengan cara mempelajari secara keseluruhan dulu, setelahnya ditindaklanjuti memperhatikan detailnya; 3) pemahaman pengetahuan, yakni dengan cara menyusun (a) konsep sementara, (b) melakukan sharing kepada orang lain agar mendapat tanggapan dan atas dasar tanggapan tersebut, (c) konsep direvisi serta dikembangkan; 4) mempraktikkan pengetahuan dan pengalaman; (5) melakukan refleksi terhadap strategi pengembangan pengetahuan yang sudah dilakukan.

\section{METODE PENELITIAN}

Penelitian ini menggunakan pendekatan penelitian kontekstual. Jenis penelitian pada penelitian ini menggunakan langkah penelitian dan pengembangan $R \& D$ yang berorientasi pada produk yakni alat penilaian yang digunakan pada ujian akhir semester dan tengah semester. Data dan Sumber data pada penelitian ini yakni diperoleh pada pembelajaran di SMA Papua Kota Sorong. Teknik pengumpulan data pada penelitian ini menggunakan observasi, wawancara, dan dokumentasi. Tahapan penelitian pada penelitian ini dimulai dari analisis kebutuhan, desain produk, validasi ahli, dan uji keefektifan. Pengembangan instrumen penilaian ujian akhir semester, tengah semester:

a. Penentuan spesifikasi ujian

Pembuatan kisi-kisi pengujian untuk mengukur semua kompotensi dasar yang tercermin dalam bahan yang diujkan persis dengan butir soal untuk tiap indicator, penentuan bentuk soal dan lama ujian bentuk soal yang akan dipilih objektif atau subjektif: pilihan ganda, benar salah, penjodohan, isian singkat dan perhitungan waktu yang tersedia 75, 90, 120 menit. 


Kredo 4 (2021)
KREDO: Jurnal Ilmiah Bahasa dan Sastra
Terakreditasi Sinta 4 berdasarkan Keputusan Direktorat
Jenderal Penguatan Riset dan Pengembangan,
Kementerian Riset, Teknologi dan Pendidikan Tinggi
Republik Indonesia
Nomor: 23/E/KPT/2019. 08 Agustus 2019
https://jurnal.umk.ac.id/index.php/kredo/index

b. Penulisan butir soal

Pada proses ini dilakukan melalui pembuatan indikator yang diaplikasikan pada bahan ajar. Isi bahan ajar memuat butir-butir soal yang disesuaikan dengan indikator sehingga sesuai dengan sasaran atau tujuan pembelajaran. Butir soal disusun berdasarkan kebutuhan dalam proses pembelajaran sehingga tidak ada yang keluar dalam koridor kompetensi pembelajaran.

c. Penelaah butir soal

Penelaahan butir soal dilakukan melalui proses pembelajaran yang dimulai dari ulangan harian, Ujian Tengah Semester, Ujian Akhir Semester yang didalamnya terdapat persoalan dalam materi pembelajaran. Soal-soal tersebut digunakan sebagai alat tes untuk mengukur tingkat keberhasilan siswa dalam mengerjakan soal-soal serta menganalisis tingkat pemahaman siswa dalam proses pembelajaran yang telah dipelajarinya.

d. Pelaksanaan ujicoba

Pelaksanaan ujicoba dilakukan setelah alat ukur berupa instrumen tes benar-benar valid dan reliabel sesuai dengan pengecekan yang telah dilakukan oleh peneliti. Kualitas dari informasi instrumen tes penting untuk diketahui sehingga pertanggungjawaban secara ilmiah dapat menjadi pedoman dari melakukan proses pembelajaran.

e. Analisis butir soal dan jawaban Analisis butir soal yang dilakukan untuk pengembangan didasarkan pada analisis tiap indikator tiap kemampuan dasar yang ada dalam pembelajaran mulai dari umpan balik pembelajaran yang didalamnya berdasarkan informasi mulai dari tingkat yang paling mudah, mudah, sampai tersulit. Indikator tingkat indeks kesulitan disingkat (ITK) dan indeks daya beda disingkat (IDB) digunakan untuk menghitung jawaban benar dan salah melalui analisis jawaban dan telaah hasil pengukuran tiap indikator. Keseluruhan butir soal diujikan pada siswa untuk mengetahui penguasan materi dan materi yang masih belum dikuasai oleh siswa.

f. Perbaikan butir soal dan perakitan soal ujian

Perbaikan butir soal dilakukan untuk memperbaiki soal-soal yang kedudukannya masih keluar dari kompetensi pembelajaran. Unsur pengecoh dalam soal dianalisis secara 


Kredo 4 (2021)
KREDO: Jurnal Ilmiah Bahasa dan Sastra
Terakreditasi Sinta 4 berdasarkan Keputusan Direktorat
Jenderal Penguatan Riset dan Pengembangan,
Kementerian Riset, Teknologi dan Pendidikan Tinggi
Republik Indonesia
Nomor: 23/E/KPT/2019. 08 Agustus 2019
https://jurnal.umk.ac.id/index.php/kredo/index

mendalam untuk mengetahui butir-butir soal tersebut memang sudah efektif dan sesuai dengan tingkatan kesulitan siswa dalam menjawab pertanyaan. Soal-soal yang kedudukannya masih perlu diperbaiki disusun kembali sesuai dengan butir-butir soal yang disarankan sehingga dapat digunakan untuk perakitan soal ujian.

g. Pelaksanaan ujian

Pelaksanaan ujian dilakukan sesuai prosedur dalam ujian yakni terdapat pengawas dan dilakukan sesuai waktu ujian berdasarkan perhitungan keterselesaian butir-butir soal yang dijawab oleh siswa. pelaksanaan ujian dilakukan sesuai dengan rambu-rambu ujian dan tidak melanggar proses ujian.

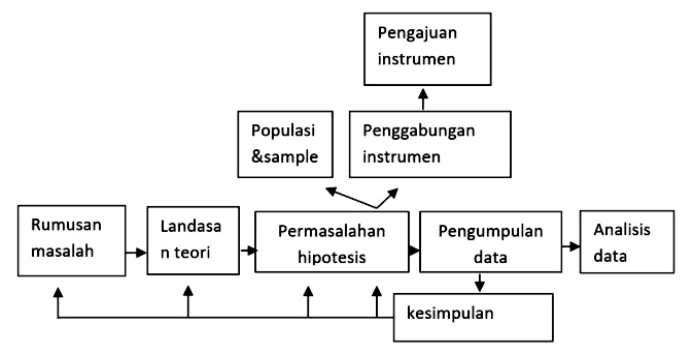

Gambar 2. Metode pelaksnaan penelitian

Metode yang digunakan adalah metode penelitian kuantitatif yang dalam penelitian ini sebagai metode ilmiah/scientific memenuhi kaidah ilmiah kongkrit/empiris, objektif, terukur, rasional ditemukan dan dikembangkan. Sejalan dengan pendekatan ini adalah pendekatan kontruktivisme bersifat deduktif. Menjawab rumusan masalah digunakan konsep dan teori sehingga dirumuskan hipotesis diuji melalui pengumpulan data lapangan.

Mengumpulkan data digunakan instrument penelitian. Data dikumpul dianalisis secara kuantitatif deskriptif. Metode analisis data digunakan penelitian sampel diambil secara random, sehingga kesimpulan hasil digeneralisasikan. Sedangkan teknik pengumpulan data dilakukan:

a. observasi yaitu pengamatan yang dilakukan secara lansung maupun tidak lansung terhadap objek yang sedang diteliti di SMA Papua kota Sorong.

b. wawancara adalah upaya yang dilakukan untuk mendapatkan keterangan atau pendapat mengenai hal yang diperlukan untuk tujuan tertentu dari pihak lain untuk Tanya jawab.

c. dokumentasi adalah pengumpulan data dengan cara mengambil data-data dari catatan, dokumentasi, administrasi, sesuai dengan masalah yang diteliti.

Sumber data, meliputi studi kepustakaan, data primer dan data sekunder, uji klasik. (Sa'dun akbar: 2013) dengan rumus. 


Kredo 4 (2021)
KREDO: Jurnal Ilmiah Bahasa dan Sastra
Terakreditasi Sinta 4 berdasarkan Keputusan Direktorat
Jenderal Penguatan Riset dan Pengembangan,
Kementerian Riset, Teknologi dan Pendidikan Tinggi
Republik Indonesia
Nomor: 23/E/KPT/2019. 08 Agustus 2019
https://jurnal.umk.ac.id/index.php/kredo/index

$$
\begin{aligned}
& V=\frac{V a+V p g+V \theta}{3}=\cdots \% \\
& V a=\frac{\tau S h}{T S_{\theta}} \times 100 \% \\
& V a=\frac{T S h}{T S_{e}} \times 100 \% \\
& V p=\frac{\tau S h}{\tau S_{\theta}} \times 100 \% \\
& V a=\frac{T S h}{T S_{\theta}} \times 100 \% \\
& \text { Di mana: } \\
& \text { Va }=\text { Validitas dari ahli } \\
& \text { Vp }=\text { Validitas dari pengguna } \\
& \text { Ve }=\text { Validitas dari audience } \\
& \text { TSh }=\text { Total Skor maksimal yang diharapkan } \\
& \text { TSe }=\text { Total skor empiris (hasil validasi dari } \\
& \text { validator) setelah nilai masing-masing uji } \\
& \text { validitas ( Akbar Sa'dun,158:2013) }
\end{aligned}
$$

\section{HASIL PENELITIAN}

Pembuatan instrumen penilaian berbasis kompetensi untuk UTS dan UAS terbagi menjadi beberapa kegiatan utama, yaitu pembuatan spesifikasi ujian, penulisan butir soal, penelaah butir soal, pelaksanaan ujicoba, analisis butir soal dan jawaban, perbaikan butir soal dan perakitan soal ujian pembuatan instrumen penilaian berbasis kompetensi dan uji coba instrumen untuk memperoleh kualitas insrumen yang valid dan reliabel. Hasil penelitian pembuatan instrumen penilaian ini dilaporkan secara deskriptif kualitatif dan kuantitatif berdasarkan tahapantahapan pada masing-masing kegiatan. Adapun hasil penelitian dapat dipaparkan sebagai berikut:

587 | Jurnal Kredo

Vol. 4 No. 22021

\section{Spesifikasi ujian}

Dalam penentuan spsifikasi ujian empat hal perlu diperhatikan. 1) penentuan kompetensi dasar mengukur banyak siswa mencapai kompetensi dipelajari. 2) pembuatan deskripsi bahan uji meliputi materi pokok, uraian materi diajarkan dalam RPP. 3) kisi-kisi ujian sebelum menulis butir soal. 4) penentuan bentuk soal segala jenis (uraian objektif, uraian esai (nonobjektif) atau gabungan dari beberapa bentuk. Menentukan berapa banyak soal diuji dan memperhitungkan waktu tersedia apakah 75, 90, 120 menit atau berapa diperlukan mengerjakan tiap butir soal antara keduanya terdapat kesesuaian.

\section{Penulisan butir soal}

Dalam penelitian penulisan butir soal membuat tagihan tuntutan indicator sesui bahan ajar. Sebelum butir soal tes disusun, terlebih dahulu ditentukan jumlah butir soal tes akan dibuat. Dasar penentuan jumlah butir soal tes adalah jenis dan bentuk tes digunakan. Untuk jenis tes objektif diperlukan jumlah butir tes jauh lebih besar dari pada tes non-objektif. Setelah ditetapkan jumlah butir soal tes dipersiapkan sesuai dengan jenis dan bentuk tes digunakan, selanjutnya dilakukan penulisan butir tes. Untuk mempermudah pengaturan, soal terlebih dahulu ditulis kartu soal seperti dibawah 


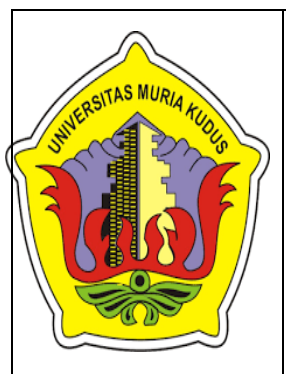

Kredo 4 (2021)

KREDO: Jurnal Ilmiah Bahasa dan Sastra

Terakreditasi Sinta 4 berdasarkan Keputusan Direktorat

Jenderal Penguatan Riset dan Pengembangan,

Kementerian Riset, Teknologi dan Pendidikan Tinggi

Republik Indonesia

Nomor: 23/E/KPT/2019. 08 Agustus 2019

https://jurnal.umk.ac.id/index.php/kredo/index

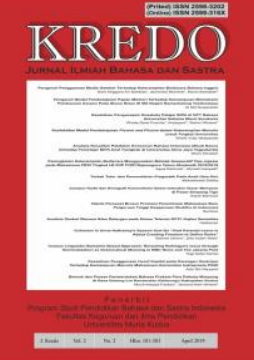

Tabel 1. kartu soal

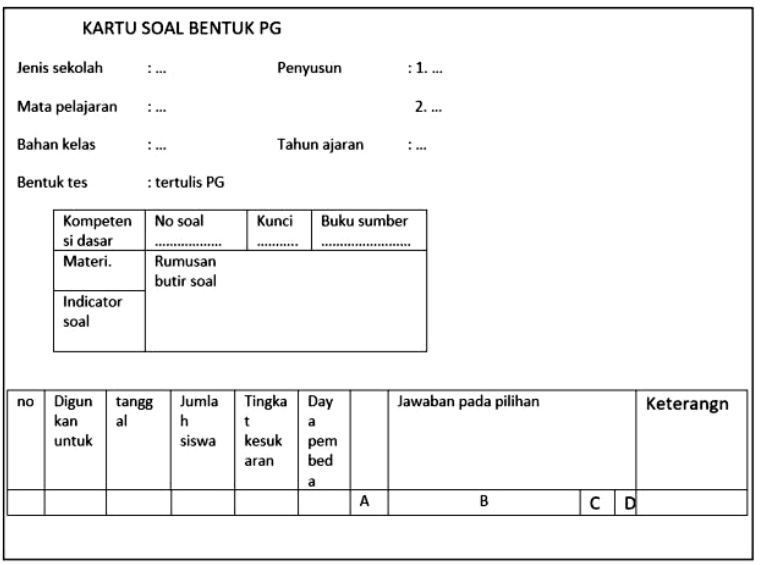

Penelaah butir soal

Kebiasaan yang sering guru selesai menulis soal ujian tengah, akhir semester lansung diujikan kepada siswa tanpa melakukan telaah terlebih dahulu terhadap alat tes bersangkutan sebelum digunakan. 1) telaah secara kualitatif, telaah teman sejawat, rumpun keahlian sama dilakukan sebelum tes diuji coba. 2) telaah secara kuantitatif, analisis hasil uji coba setelah tes diuji. Hasil telaah merupakan perbaikan tes. Selanjutnya hasil tes dianalisis mengetahui kompetensi dasar dicapai dan belum dicapai. telaah butir tes dilakukan ranah materi subtansi keilmuan ditanyakan tingkat berpikir terlibat. Rana kontruksi teknik penulisan soal, bentuk objektif subjektif, dan ranah bahasa berkaitan kekomunikatifan kejelasan ditanyakan. Sebagai berikut:

Tabel 2. Penelaah butir soal

\begin{tabular}{|l|c|c|c|c|c|c|c|c|c|}
\hline $\begin{array}{l}\text { Jenis } \\
\text { persyaratan }\end{array}$ & $\mathrm{N}$ & $\mathrm{O}$ & $\mathrm{M}$ & $\mathrm{O}$ & $\mathrm{R}$ & $\mathrm{S}$ & $\mathrm{O}$ & $\mathrm{A}$ & $\mathrm{L}$ \\
\hline A. Ranah & 1 & 2 & 3 & 4 & 5 & $\ldots$ & & & \\
\hline
\end{tabular}

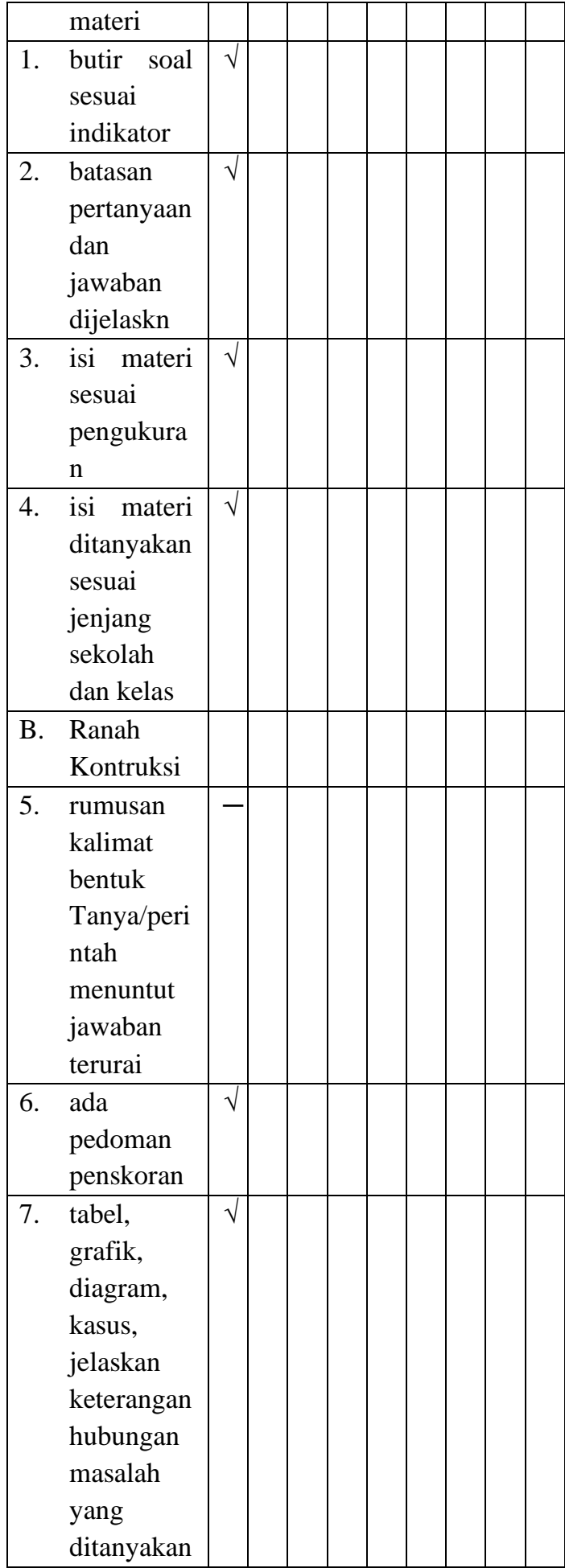




Kredo 4 (2021)
KREDO: Jurnal Ilmiah Bahasa dan Sastra
Terakreditasi Sinta 4 berdasarkan Keputusan Direktorat
Jenderal Penguatan Riset dan Pengembangan,
Kementerian Riset, Teknologi dan Pendidikan Tinggi
Republik Indonesia
Nomor: 23/E/KPT/2019. 08 Agustus 2019
https://jurnal.umk.ac.id/index.php/kredo/index

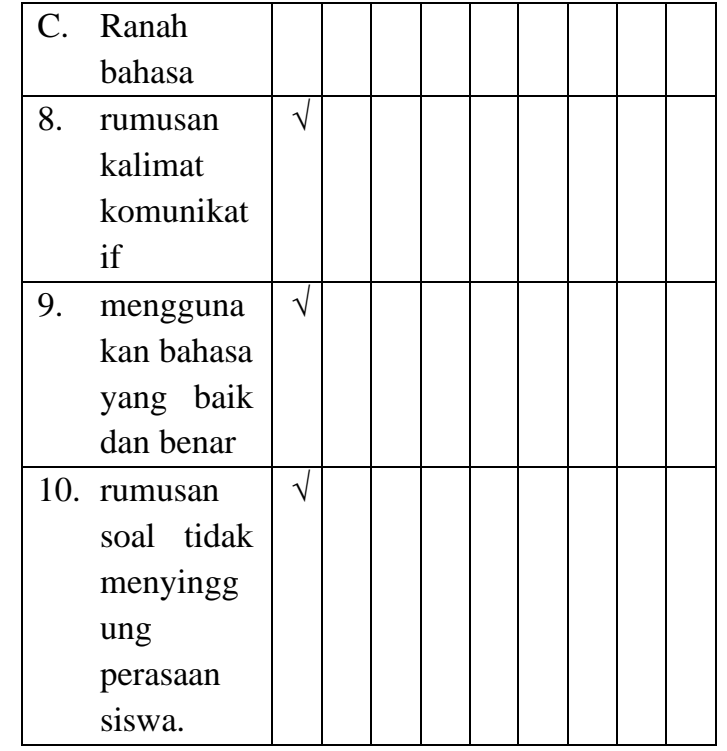

\section{Telaah Hasil Pengukuran}

\section{Kemampuan Berbahasa Peserta}

\section{Didik}

\begin{tabular}{|c|c|c|c|c|c|c|c|}
\hline $\begin{array}{l}\mathrm{N} \\
\mathrm{O}\end{array}$ & $\begin{array}{c}\text { Kem } \\
\text { ampu } \\
\text { an } \\
\text { dasar } \\
\text { (KD) }\end{array}$ & $\begin{array}{c}\text { Ind } \\
\text { kat } \\
\text { or } \\
\text { (ju } \\
\text { mla } \\
\text { h } \\
\text { soa } \\
\text { ) }\end{array}$ & $\begin{array}{l}\mathrm{Ju} \\
\mathrm{ml} \\
\mathrm{ah} \\
\mathrm{bu} \\
\mathrm{tir} \\
\text { (K } \\
\mathrm{D})\end{array}$ & $\begin{array}{l}\mathrm{Ju} \\
\mathrm{m} \\
\text { ah } \\
\text { be } \\
\text { tul }\end{array}$ & $\begin{array}{l}\mathrm{P} \\
\mathrm{rs} \\
\mathrm{nt} \\
\mathrm{as} \\
\mathrm{e} \\
\mathrm{ca} \\
\mathrm{pa} \\
\text { ia } \\
\mathrm{n}\end{array}$ & $\begin{array}{l}\mathrm{Pe} \\
\text { ng } \\
\text { ua } \\
\text { sa } \\
\text { an }\end{array}$ & $\begin{array}{l}\mathrm{ke} \\
\text { te } \\
\mathrm{ra} \\
\mathrm{ng} \\
\text { an }\end{array}$ \\
\hline 1 & & $\begin{array}{l}1 \\
(2) \\
2 \\
(3) \\
3 \\
(3)\end{array}$ & 8 & 6 & 75 & $\mathrm{~V}$ & \\
\hline \multicolumn{8}{|l|}{2} \\
\hline$\ldots$ & & & & & & & \\
\hline \multicolumn{2}{|c|}{ Jumlah } & 60 & 60 & 48 & 80 & $\mathrm{~V}$ & \\
\hline
\end{tabular}

spesifikasi analisis hasil tes

Nama Peserta Didik: Diva Dalas

\begin{tabular}{|c|c|c|c|c|c|}
\hline $\begin{array}{c}\text { Ko } \\
\text { mp } \\
\text { ote } \\
\text { nsi } \\
\text { Das } \\
\text { ar }\end{array}$ & $\begin{array}{c}\mathbf{J} \\
\mathbf{u} \\
\mathbf{m} \\
\text { la } \\
\mathbf{h} \\
\text { B } \\
\text { ut } \\
\text { ir }\end{array}$ & $\begin{array}{c}\text { Ju } \\
\text { mla } \\
\text { h } \\
\text { yan } \\
\text { g } \\
\text { bet } \\
\text { ul }\end{array}$ & $\begin{array}{c}\text { Per } \\
\text { sent } \\
\text { ase } \\
\text { pen } \\
\text { cap } \\
\text { aia } \\
\text { n }\end{array}$ & $\begin{array}{c}P \\
\text { en } \\
\mathbf{g} \\
\mathbf{u} \\
\text { as } \\
\text { aa } \\
\mathbf{n}\end{array}$ & Keterangan \\
\hline $\begin{array}{l}\text { Me } \\
\text { mba } \\
\text { ca } \\
\text { ekst } \\
\text { ensi } \\
\text { f } \\
\text { teks } \\
\text { non } \\
\text { sast } \\
\text { ra } \\
\text { dari } \\
\text { ber } \\
\text { bag } \\
\text { ai } \\
\text { sum } \\
\text { ber }\end{array}$ & 20 & 15 & 75 & $\mathrm{~V}$ & $\begin{array}{l}\text { Menguasai } \\
\text { dalam } \\
\text { menentukan } \\
\text { gagasan } \\
\text { pokok setiap } \\
\text { teks bacana } \\
\text { dan } \\
\text { menguasai } \\
\text { persamaan } \\
\text { dan } \\
\text { perbedaan } \\
\text { gagasan } \\
\text { pokok } \\
\text { masing- } \\
\text { masing teks } \\
\text { bacaan, } \\
\text { tetapi belum } \\
\text { menguasai } \\
\text { kemungkina } \\
\text { n terjadinya } \\
\text { perbedaan } \\
\text { gagasan } \\
\text { pokok } \\
\text { antarteks } \\
\text { dari sudut } \\
\text { pandang } \\
\text { pengarang. }\end{array}$ \\
\hline
\end{tabular}

\section{Pelaksanaan uji coba}

Untuk uji coba pelaksanaan pengukuran dengan menggunakan instrumen tes yang telah dikembangkan. Dari pelaksanaan pengukuran diperoleh 


Kredo 4 (2021)
KREDO: Jurnal Ilmiah Bahasa dan Sastra
Terakreditasi Sinta 4 berdasarkan Keputusan Direktorat
Jenderal Penguatan Riset dan Pengembangan,
Kementerian Riset, Teknologi dan Pendidikan Tinggi
Republik Indonesia
Nomor: 23/E/KPT/2019. 08 Agustus 2019
https://jurnal.umk.ac.id/index.php/kredo/index

data empiric menunjukan kualitas hasil ujian sebagai capaian siswa menguasai berbagai kompetensi yang dibelajarkan, tampaknya para guru tidak melakukan uji coba terhadap alat tes dikembangkan untuk mengukur capain siswa sendiri.

\section{Perbaikan butir soal dan Perakitan soal ujian}

Butir tes baik (memenuhi persyaratan) ditata atau dirakit dengan cara tertentu. Dalam merakit soal ujian, butir soal dapat dikelompokan menutur urutan kompetensi dasar, taraf kesukaran, dan format (kompetensi bentuk soal). Urutan soal tiap kompetensi dasar diurutkan menurut tingkat kesulitannya mudah ke sulit. Berdasarkan format, urutan soal dimulai dari isian singkat, pilihan ganda, dan terakhir uraian.

\section{PEMBAHASAN}

\begin{tabular}{rrr}
\multicolumn{2}{c}{ Berdasarkan hasil yang } \\
diperoleh dari & pelaksanaan
\end{tabular} pengembangan alat penilaian ada dua hal yang erat berkaitan dalam kegiatan belajar mengajar guru di SMA Papua Kota Sorong. Pertama alat penilaian yang disusun itu sebenarnya tidak sesuai atau tidak memeliki tujuan yang jelas, untuk mengukur kompetensi dasar atau indicator yang mana. Sebaliknya ada tujuan tetapi justru tidak dikembangkan alat penilaiannya. Kedua guru tidak merakit soal ujian dalam bentuk kisi-kisi soal dan kartu soal kemudian dikembangkan menjadi soal.

Mengingat pentingnya alat penilaian bagi guru dari spesifikasi ujian dengan penentuan kompetensi dasar untuk mencapai tujuan, pembuatan deskripsi bahan ajar yang akan ditagih capaian yang jelas, pembuatan kisi-kisi ujian yang bercermin pada bahan ajar dan indicator dan pembentukan soal dan lama ujian pilihan ganda, benar salah, penjodohan, esai, uraian, objektif, subjektif. Selajutnya guru berpikir untuk penulisan butir soal sesuai kata kerja operasional, menelaah butir soal mana yang sesuai atau tidak, pelaksaan uji coba, hasil dari ujicoba dianalisis butir soal dan jawabannya sampai perbaiakn butir soal dan perakitan soal ujian.

Berdasarkan penelitian yang dilakukan oleh Aji dan Winarno (2016), Suarga (2019) dengan penelitian yang dilakukan oleh peneliti bahwa penilaian sangat penting untuk dilakukan mengingat bahwa penilaian merupakan dasar dari mengetahui secara detail tentang kemampuan dan keahlian siswa dalam belajar dan mengidentifikasi dengan baik keunggulan dan kekurangan siswa dalam pembelajaran. Selain itu dalam proses pembelajaran, peran penilaian dapat berguna melalui perannya dalam menilai kelengkapan perangkat pembelajaran mulai dari model, teknik pembelajaran, media, dan 


Kredo 4 (2021)
KREDO: Jurnal Ilmiah Bahasa dan Sastra
Terakreditasi Sinta 4 berdasarkan Keputusan Direktorat
Jenderal Penguatan Riset dan Pengembangan,
Kementerian Riset, Teknologi dan Pendidikan Tinggi
Republik Indonesia
Nomor: 23/E/KPT/2019. 08 Agustus 2019
https://jurnal.umk.ac.id/index.php/kredo/index

kreativitas guru dalam mengajar yang berdampak pada keahlian siswa semakin baik.

\section{SIMPULAN}

Hasil pelaksanaan pengembangan alat penilaian berbasis kompetensi didukung dengan penelitian terdahulu dan berbagai pendapat pakar dapat disimpulkan bahwa penggunaan pengembangan alat pembelajaran berbasis kompetensi di SMA Papua Kota sorong, dapat ditingkatkan apabila pendidik memahami dan kreatif, berusaha untuk menyusun bahan penilaian sesuai dengan ketentuan dan aturan seorang pendidik. Pemanfaatan pendekatan kontekstual yang mengarah pada pemahaman siswa terhadap lingkungannya dapat mendorong siswa untuk memahami lingkungan dalam proses pembelajaran sehingga siswa dalam belajar mampu mempraktikkan langsung dalam kehidupan. Hal-hal yang mengedepankan budaya lokal dalam pembelajaran tentunya dikedepankan untuk mendorong siswa dalam melestarikan budaya lokal dan lingkungannya agar terjaga dengan baik dan dapat meningkatkan sumber daya alam.

\section{SARAN}

Hasil penelitian pada guru-guru SMA Papua Kota Sorong dapat meningkatkan pengembangan alat penilaian berbasis kompetensi sebagai berikut:

1) Untuk mengembangkan alat penialain berbasis kompetensi menekankan pentingnya penilaian proses untuk mengetahui kemajuan belajar peserta didik.

2) Pendidik perlu mengembangkan alat penilaian yang dapat dipertanggungjawabkan

3) Dari penelitian tersebut, akan dijadikan sebagai masukan untuk pertimbangan pengambilan kebijakan di dalam pengembangan alat penilaian pembelajaran akan meningkat/maju.

4) Pendidik wajib menyiapkan alat penilaian untuk menilai keberhasilan hasil pembelajaran UAS dan UTS.

\section{DAFTAR PUSTAKA}

Aji, B S., Winarno, M, E. 2016. Pengembangan Instrumen Penilaian Pengetahuan Mata Pelajaran Pendidikan Jasmani Olahraga dan Kesehatan (PJOK) Kelas VIII Semester Gasal. Jurnal Pendidikan: Teori, Penelitian, \& Pengembangan, 1(7). Malang: Universitas Negeri Malang. 


Kredo 4 (2021)
KREDO: Jurnal Ilmiah Bahasa dan Sastra
Terakreditasi Sinta 4 berdasarkan Keputusan Direktorat
Jenderal Penguatan Riset dan Pengembangan,
Kementerian Riset, Teknologi dan Pendidikan Tinggi
Republik Indonesia
Nomor: 23/E/KPT/2019. 08 Agustus 2019
https://jurnal.umk.ac.id/index.php/kredo/index

Akbar Sa'dun, 2013. Instrumen Perangkat Mengajar. Bandung: Rosda.

Fawzi, A. 2016. Pengembangan Alat Penilaian Pembelajaran Menyimak Eksposisi Kelas X SMA. Jurnal Bahasa dan Seni, 44(2). Malang: Universitas Negeri Malang Indonesia.

Iskandarwassid, Sunendar Dadang, 2013. Strategi Pembelajaran Bahasa. Bandung: Rosda.

Irwan Soulisa, 2018. Analisis Silabus dan SAP Dosen Program Studi Pendidikan Bahasa dan Sastra Indonesia Universitas Victory Sorong. Jurnal online Hasta Wiyata.

Kunandar, 2013. Penilaian Autentik suatu Pendektan Praktis. Jagakarsa: Raja Grapindo Perkasa.

Nurgiantoro Burhan, 2010. Penilaian Pembelajaran Bahasa Berbasis Kompetensi. Yogyakarta: BPTE.

Pardjono., Windiyati, H. 2012. Implementasi Pembelajaran Berbasis Kompetensi di SMK. Jurnal Cakrawala Pendidikan, XXXI (2). Yogyakarta: Lembaga Pengembangan dan Penjaminan Mutu Pendidikan UNY.

Priyanti Endah Tri, 2014. Desain Pembelajaran Bahasa Indonesia Kurikulum 2013. Malang: Bumi aksara.

Pribadi Benny A, 2009. Model System Pembelajaran. Jakarta: Dian Rakyat.

Subagia, I W., Wiratma, I G L. 2016 Profil Penilaian Hasil Belajar Siswa Berdasarkan Kurikulum 2013. Jurnal Pendidikan Indonesia, 5(1). Singaraja Bali: Lembaga Penelitian Dan Pengabdian Kepada Masyarakat (LPPM) Universitas Pendidikan Ganesha.

Sulianto, J. Pendekatan Kontekstual dalam Pembelajaran Matematika untuk Meningkatkan Berpikir Kritis pada Siswa Sekolah Dasar. Pythagoras, 4(2). Yogyakarta: Department of Mathematics Education, Faculty of Mathematics and Natural Sciences, Universitas Negeri Yogyakarta. 


Kredo 4 (2021)
KREDO: Jurnal Ilmiah Bahasa dan Sastra
Terakreditasi Sinta 4 berdasarkan Keputusan Direktorat
Jenderal Penguatan Riset dan Pengembangan,
Kementerian Riset, Teknologi dan Pendidikan Tinggi
Republik Indonesia
Nomor: 23/E/KPT/2019. 08 Agustus 2019
https://jurnal.umk.ac.id/index.php/kredo/index

Suryanti, Sukestyarno, Fakhrudin. 2013. Pengembangan Alat Penilaian Kinerja Pembelajaran dengan Metode CTL Berbasis Karakter. Journal of Educational Research and Evaluation, 2(1). Semarang. Universitas Negeri Semarang.

Suarga. 2019. Hakikat, Tujuan, dan Fungsi Evaluasi dalam Pengembangan Pembelajaran. Jurnal Inspiratif Pendidikan, 8 (2). Sulawesi Selatan: Department of Islamic Education Universitas Islam Negeri Alauddin Makassar.

Suteja, J. 2017. Model-Model Pembelajaran dalam Kurikulum Berbasis Kompetensi KKNI di Perguruan Tinggi (Perubahan dari Teacher Centered Learning ke Arah Student Centered Learning), Jurnal Pendidikan Sosial dan Ekonomi 6(1). Cirebon: Tadris IPS, IAIN Syekh Nurjati Cirebon.

Sogiyono, 2013. Metode Penelitian Kombinasi. Bandung: Alfabeta.

Wahyudi. 2010. Asesmen Pembelajaran Berbasis Portofolio di Sekolah. Jurnal Visi Ilmu Pendidikan, 2(1). Pontianak: Universitas Tanjungpura.

Wiyani Novan Ardi, 2013. Desain Pembelajaran Pendidikan. Yogyakarta: Ar ruzzmedia.

Wulandari, A. D., Situmorang, R. P., Dewi L. 2018. Evaluasi Pelaksanaan Penilaian Autentik pada Pembelajaran IPA terhadap Hasil Belajar Peserta Didik Kelas VIII SMP Negeri 3 Salatiga. Jurnal Pendidikan Sains, 6(1). Semarang: Department of Chemistry Education, Faculty of Mathematics and Natural Science, Universitas Muhammadiyah Semarang, Indonesia.

Zulaiha, S. 2016. Pendekatan Contextual Teaching and Learning (CTL) dan Implementasinya dalam Rencana Pembelajaran PAI MI. BELAJEA: Jurnal Pendidikan Islam, 1(1). Curup: Sekolah Tinggi Agama Islam Negeri (STAIN) Curup, Indonesia.

593 | Jurnal Kredo

Vol. 4 No. 22021 